\title{
Correction to: Are the existing eu ecolabel criteria for furniture products too complex? An analysis of complexity from a material and a supply chain perspective and suggestions for ways ahead
}

\author{
Shane Donatello ${ }^{1} \cdot$ Mauro Cordella $^{1} \cdot$ Renata Kaps $^{1} \cdot$ Malgorzata Kowalska $^{1} \cdot$ Oliver Wolf $^{1}$ \\ Published online: 7 October 2021 \\ (c) The Author(s) 2021
}

\section{Correction to: The International Journal of Life Cycle Assessment (2020) 25:868-882 https://doi.org/10.1007/s11367-019-01601-1}

The article "Are the existing EU Ecolabel criteria for furniture products too complex? An analysis of complexity from a material and a supply chain perspective and suggestions for ways ahead", written by Shane Donatello, Mauro Cordella, Renata Kaps, Malgorzata Kowalska1 \& Oliver Wolf1, was originally published Online First without Open Access.

After publication in volume, issue, page the author decided to opt for Open Choice and to make the article an Open Access publication. Therefore, the copyright of the article has been changed to (C) The Author(s) 2021 and the article is forthwith distributed under a Creative Commons Attribution 4.0 International License, which permits use, sharing, adaptation, distribution, and reproduction in any medium or format, as long as you give appropriate credit to the original author(s) and the source, provide a link to the Creative Commons license, and indicate if changes were made. The images or other third party material in this article are included in the article's Creative Commons license, unless indicated otherwise in a credit line to the material. If material is not included in the article's Creative Commons license and your intended use is not permitted by statutory regulation or exceeds the permitted use, you will need to obtain permission directly from the copyright holder. To view a copy of this license, visit http://creativecommons. org/licenses/by/4.0/.

Open Access This article is licensed under a Creative Commons Attribution 4.0 International License, which permits use, sharing, adaptation, distribution and reproduction in any medium or format, as long as you give appropriate credit to the original author(s) and the source, provide a link to the Creative Commons licence, and indicate if changes were made. The images or other third party material in this article are included in the article's Creative Commons licence, unless indicated otherwise in a credit line to the material. If material is not included in the article's Creative Commons licence and your intended use is not permitted by statutory regulation or exceeds the permitted use, you will need to obtain permission directly from the copyright holder. To view a copy of this licence, visit http://creativecommons.org/licenses/by/4.0/.

Publisher's Note Springer Nature remains neutral with regard to jurisdictional claims in published maps and institutional affiliations.

The original article can be found online at https://doi.org/10.1007/ s11367-019-01601-1.

Shane Donatello

shane.donatello@ec.europa.eu

1 Circular Economy and Industrial Leadership Unit, European

Commission, Joint Research Centre (JRC), Seville, Spain 